\title{
Entrepreneurship ecosystem in the United Arab Emirates: An empirical comparison with Qatar and Saudi Arabia
}

\author{
Ayman Balawi
}

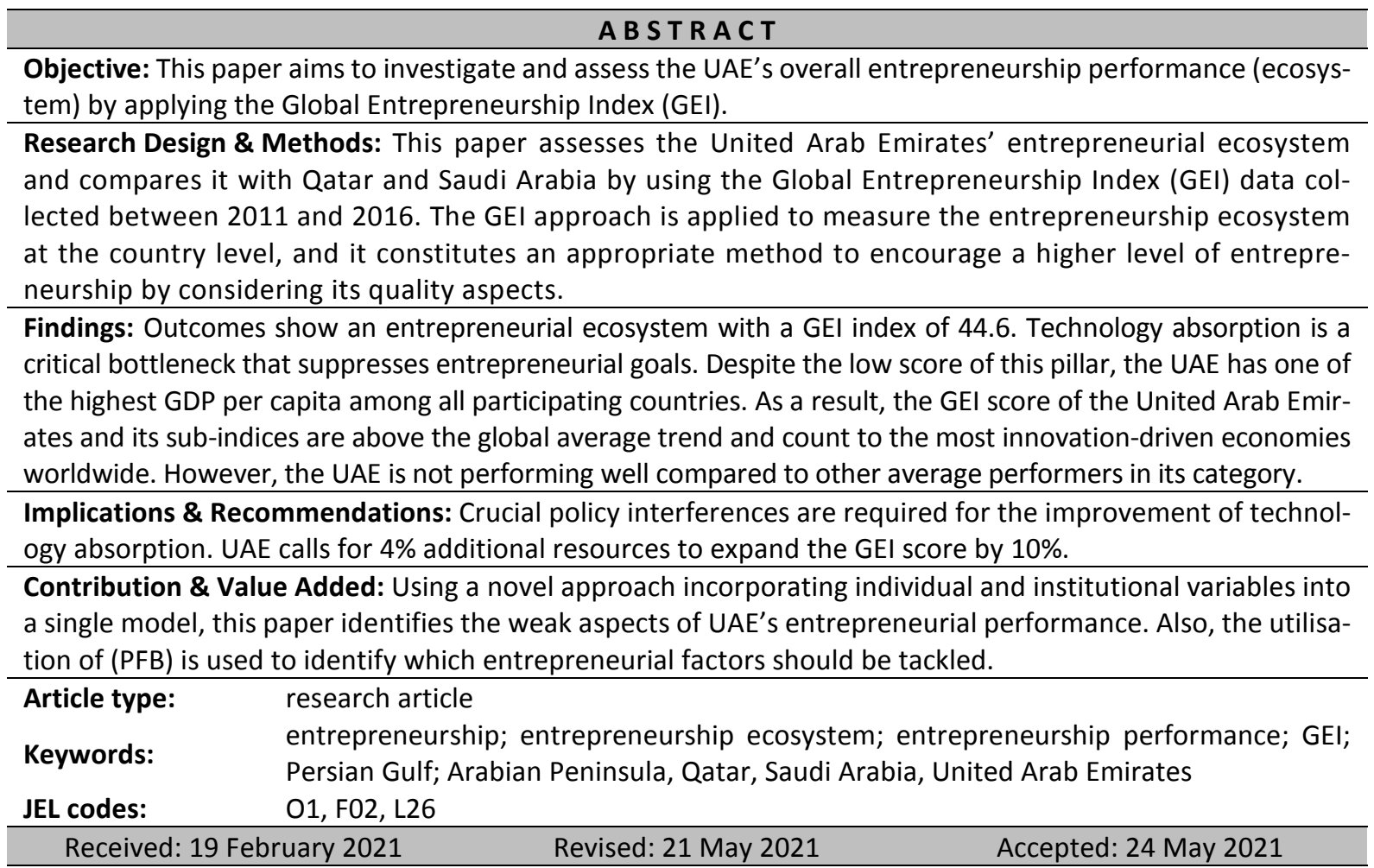

Suggested citation:

Balawi, A. (2021). Entrepreneurship ecosystem in the United Arab Emirates: An empirical comparison with Qatar and Saudi Arabia. International Entrepreneurship Review, 7(2), 55-66. https://doi.org/10.15678/ IER.2021.0702.05

\section{INTRODUCTION}

The United Arab Emirates (UAE) is well-known for being one of the most eye-catching places for investments in the world. It is one of the fastest rising economies in the region (the Arabian Peninsula, the Persian Gulf), and it has attracted significant investments, new firms, and entrepreneurs. An integrated system of regulations has achieved this inspiring accomplishment, commercial and labour laws, endorsed by the government to boost investments and projects and nurture a suitable environment for entrepreneurs and investors alike (Cummings, 2018; Hamdan, 2019). Before the exploration of oil in the mid-1950s, the Emirates' economy was predominantly driven by agriculture in oases, date palm trading, and fishing. At present, the UAE economy is highly dominated by extractive industries - including crude oil and natural gas (29.50\%), wholesale and retail trade $(11.70 \%)$, financial and insurance activities (8.60\%), construction and building (8.40\%). The UAE adopts economic diversification strategies, which have successfully boosted non-oil sectors' contribution to the 
national economy, such as manufacturing, tourism, banking, trade, real estate, services, and renewable energy (UAE Portal, 2020).

Furthermore, the UAE takes concrete steps to upsurge these sectors' impact on the national economy to reach $80 \%$ in 2021 . Thus, the oil industry's contribution is currently about $30 \%$ of GDP, compared to $79 \%$ in 1980 (UAE Portal, 2020). Based on that, the UAE has settled several strategies and plans in line with the best global practices in strategic planning and development. In 2010, the Emirates launched the UAE Vision 2021, which "sets the key themes for the Social and economic development of the UAE" - a vision that aims to make the UAE one of the best countries in the world. To achieve this goal, the country launched the "National Agenda", which includes key performance indicators (KPIs) that serve as a guide for the country in achieving its aspirations. These KPIs have been sectioned into six national pillars representing the six main sectors of fundamental interest of the UAE: Health, Security, Infrastructure, Education, Economy, and Housing. These indicators could be compared with other promising projects in the region, such as Saudi Vision 2030 (UAE Portal, 2020; Vision2021, 2019).

The Emirates' economy has experienced a significant transformation in the last ten years. The GDP has increased from 290 billion USD in 2010 to 414 billion USD in 2018, at an annual growth rate exceeding 9\% during 2010-2018. Throughout these years, the country's focus was on establishing a differentiated economy, along with large-scale infrastructure development. As a result, economic growth has led to vital progress in its citizens' living standards and job opportunities for foreigners. To reinforce its position, the UAE has established a framework that is continuously adapting the highest international standards to meet the entrepreneurial community's requirements. These efforts have created a rich and attractive economic environment for investments, leading to many of the best regional companies setting up their headquarters in the UAE. Consequently, the UAE became a leading economic centre in the Middle East (Al Saiqal, Ryan \& Parcero, 2018).

This paper aims to investigate and assess the UAE's overall entrepreneurship performance (entrepreneurial ecosystem) by utilizing the Global Entrepreneurship Index (GEI); this unique approach combines institutional and individual variables. We used this methodology to compare the UAE profile with the leading economies in the region (Qatar and Saudi Arabia). It the first paper that examines the UAE entrepreneurship development by using the GEI. Furthermore, this structure, in which we have been able to discern and understand the usage of this tool, helps us to recognise and understand the country's pros and cons and their influence on the economy. The results show that the entrepreneurial performance of the UAE is all above the global average trend, that put the country into the world's innovationdriven economies, where the UAE ranked 34th among the total of 95 countries in the index.

The paper is structured as follows. First, it shows an overview of the UAE situation, followed by a description of the Emirates' current performance regarding entrepreneurship profile and macroeconomics progress. After that, it summarises the concept of the GEI methodology and differentiates it over other entrepreneurship measurements. Fourth, it analyses the Emirates' overall GEl score by clarifying the three sub-index groups, the performance of the 14 pillars in comparison to other neighbouring countries, and the performance of the two main variables (individual vs institutional). The following section suggests policy recommendations to enhance the overall entrepreneurial performance in the $\mathrm{UAE}$, while the closing section outlines a brief conclusion.

\section{LITERATURE REVIEW}

Entrepreneurship and small and medium-sized enterprises (SMEs) are one of the most important factors contributing to economic growth and employment in both developed and developing countries (Ubrežiová et al., 2008) in various economies in the world (Wach, 2015; Lubbadeh, 2019; Szerb \& Trumbull, 2018). Entrepreneurship development depends on both internal factors (traits of an entrepreneur) and external factors (business environment) (Wach \& Głodowska, 2021; Głodowska et al., 2016). Kahn (2016) underscores that the entrepreneurial ecosystem plays a crucial role especially in the Persian Gulf countries (Table 1). Similarly, Lane (2016) underlines the importance of the environment for entrepreneurship, innovation and creativity, especially in the context of university education. 
Table 1. Isenberg's domains of the entrepreneurship ecosystem

\begin{tabular}{|c|c|c|c|c|c|}
\hline \multicolumn{2}{|c|}{ Strategic domain } & \multicolumn{3}{|c|}{ Support domain } & \multirow{2}{*}{$\begin{array}{l}\text { Culture } \\
\text { domain }\end{array}$} \\
\hline Policy & Human Capital & Markets & Finance & Support Services & \\
\hline $\begin{array}{l}\text { Government } \\
\text { Institutions: } \\
\text { - Financial Sup- } \\
\text { port } \\
\text { - Laws and rules, } \\
\text { e.g. tax benefits } \\
\text { - Developing re- } \\
\text { search institu- } \\
\text { tions } \\
\text { - Business- } \\
\text { friendly laws } \\
\text { - Contract en- } \\
\text { forcement, } \\
\text { - Labour rights }\end{array}$ & $\begin{array}{l}\text { Labour: } \\
\text { - Skilled and Un- } \\
\text { skilled } \\
\text { - Serial Entrepre- } \\
\text { neurs } \\
\text { - Colleges and } \\
\text { Universities } \\
\text { - Entrepreneur- } \\
\text { ship Training }\end{array}$ & $\begin{array}{l}\text { Expertise: } \\
\text { Expert } \\
\text { knowledge and } \\
\text { information for } \\
\text { dissemination to } \\
\text { enterprise }\end{array}$ & $\begin{array}{l}\text { Micro loans: } \\
\text { Essential loans } \\
\text { for the survival of } \\
\text { micro-scale busi- } \\
\text { nesses that gen- } \\
\text { erate jobs }\end{array}$ & $\begin{array}{l}\text { Infrastructure: } \\
\text { - Telecoms } \\
\text { - Transportation } \\
\text { - Energy } \\
\text { - Industrial zones } \\
\text { - Incubators } \\
\text { - Clusters }\end{array}$ & $\begin{array}{l}\text { Success Stories: } \\
\text { - Visible Success } \\
\text { - Wealth genera- } \\
\text { tion } \\
\text { - for founders } \\
\text { - International } \\
\text { - reputation }\end{array}$ \\
\hline \multirow{2}{*}{$\begin{array}{l}\text { Leadership: } \\
\text { - Clear support } \\
\text { - Society support } \\
\text { by recognizing } \\
\text { the } \\
\text { - SME/Micro } \\
\text { business as via- } \\
\text { ble and respect- } \\
\text { able work }\end{array}$} & & \multirow{2}{*}{$\begin{array}{l}\text { Networks: } \\
\text { - Personal net- } \\
\text { works of entre- } \\
\text { preneurs } \\
\text { - Diaspora net- } \\
\text { works around } \\
\text { the markets } \\
\text { - Multinational } \\
\text { corporations }\end{array}$} & \multirow{2}{*}{\begin{tabular}{|l} 
Investment (by): \\
- Angel investors \\
- Crowd Investors \\
- Institutional In- \\
vestors \\
- Venture Capital \\
- Private Equity \\
- Pubic Capital \\
- Markets
\end{tabular}} & $\begin{array}{l}\text { Support } \\
\text { Professions: } \\
\text { - Legal } \\
\text { - Accounting } \\
\text { - Investment } \\
\text { - Advisors } \\
\end{array}$ & \multirow{2}{*}{$\begin{array}{l}\text { Societal Norms: } \\
\text { - Tolerance of } \\
\text { Risks, Failures } \\
\text { and mistakes } \\
\text { - Innovation, Cre- } \\
\text { ativity and Ex- } \\
\text { perimentation } \\
\text { - Social Status of } \\
\text { Entrepreneur } \\
\text { - Wealth Creation } \\
\text { - Ambition, Drive, } \\
\text { Hunger }\end{array}$} \\
\hline & & & & $\begin{array}{l}\text { Non-Govern- } \\
\text { ment Institu- } \\
\text { tions: } \\
\text { - Business plan- } \\
\text { ning contests } \\
\text { - Conferences }\end{array}$ & \\
\hline
\end{tabular}

Source: Rahatullah (2013) quoted in Kahn (2016).

In the UAE, entrepreneurship is not only linked with various benefits like job creation but promoting social and economic unity, which is vital to competition and productivity improvement, unlocking individual potential and producing jobs that offer a variety of choices to the citizens (Al Saiqal, Ryan \& Parcero, 2018). From the entrepreneurial ecosystem point of view, the UAE has been working well to create a conducive environment for entrepreneurs, from a robust and broad official framework that protects both investors and entrepreneurs to establish policies that connect new firms with other private institutions and public sectors. These actions and drives, combined with fast improvements of the local economy, have converted the UAE into one of the first choices of destinations for entrepreneurs in the region (Hamdan, 2019). However, to view the nature of entrepreneurship in the UAE context, it is vital to consider the various individual characteristics and traits of Emirati Entrepreneurs. The Emirati entrepreneur profile is predominantly male, aged between 25 and 34, of higher income level, employed, and having at least some post-secondary education. The primary drive for $70 \%$ of Emiratis to launch a business is to expand personal income.

Furthermore, Emirati entrepreneurs have positive views about entrepreneurship and are very optimistic about entrepreneurial opportunities, but they are hesitant towards starting a business as they have a high level of fear of failure (Minhas, 2019; El-Sokari et al., 2013). Due to intense rivalry, entrepreneurs in the UAE face problems investing their money in new business ideas. The fear of failure is mainly driven by lack of knowledge about government support, absence of business knowledge and weak skills, and undesirable perceptions of self-employment and risk-taking (Hameed et al., 2016; OECD, 2013). On the other hand, Khalilov and Yi (2021) underscore the importance of studying the relationship between institutions and entrepreneurship. They found that compared with other countries, OECD countries have 
more developed institutions and are considered the best entrepreneurial countries. Furthermore, a society with developed business activities is having a positive impact on the situation of entrepreneurs. In addition, due to its innovative nature, entrepreneurship has been a key driver of economic growth. Also, human capital provides sustainable economic growth as a key source of innovation.

\section{RESEARCH METHODOLOGY}

Ács et al. (2014) introduced the Global Entrepreneurship Index (GEI), it is one of the most renowned measures associated with entrepreneurship and economic development. GEI is a complex health indicator of the entrepreneurial ecosystem in a particular country. It has been established to measure entrepreneurship at the country level. Moreover, GEl offers four unique advantages over other entrepreneurship ecosystem measurements. First, GEl is a proper measure that considers the quality aspects of entrepreneurship over the quantity-based approach. Second, it considers both the individual and institutional aspects of entrepreneurship and various entrepreneurship elements that interact to make an entrepreneurial ecosystem. Third, GEl addresses the 14 pillars as the integrated entrepreneurship elements, not as independent elements. Fourth, GEI provides the entrepreneurship policy point of view through equalising/normalising the same marginal effect for the averages 14 pillars values, and it considers the weakest or bottleneck pillars in the system. (Szerb et al., 2018). However, GEI has some limitations in terms of accessing data, since part of the data source is based on GEM indicators that are only partially publicly available; also, other institutional indicators (13 out of 24 indicators) that GEI applied are coming from the World Economic Forum (WEF) which are not available anymore (GEM, 2018; Ács et al., 2018).

Szerb and Trumbull (2018) argue that the GEl's capability to assess the holistic entrepreneurship ecosystem makes it superior. In its structure, GEI comprises the three main sub-indexes; entrepreneurial attitudes (ATT), entrepreneurial abilities (ABT), and entrepreneurial aspiration (ASP). Each Sub-index consists of 4-5 pillars (14 pillars altogether), and each one of these pillars includes both institutional and individual variables that represent all environmental characteristics of entrepreneurship. The pillars are the basic building blocks of the sub-indices, and the value of a sub-index for a given country is the simple average of its penalty for bottleneck (PFB) adjusted pillars for that sub-index multiplied by 100. Then GEI, the super-index, is just the three sub-indices' average (Szerb et al., 2016). While the previously mentioned measures consider mostly individual variables, the GEI combines individual data with contextual institutional factors. Thus, we can get a precise representation of the ecosystem by using both institutional and individual variables.

Moreover, by measuring all pillars and analysing the three sub-indexes (ATT, ABT, ASP) on institutional and individual variables, the GEl eventually offers the PFB methodology to provide recommended policy directions for participating countries. In the PFB methodology, a bottleneck is defined as the weakest link in the national entrepreneurial dynamic; in other words, it is simply the weakest performing pillar. The PFB will be higher if there are bigger differences among the entrepreneurship variables. Therefore, the PFB will be optimised by normalising the values of all index elements, the value of each element is "penalised" by associating it to the score of the indicator with the weakest performance in each country. This simulates the bottleneck concept; if the bottleneck component is optimised, the particular sub-index and, ultimately, the GEl index will demonstrate a significant improvement. Hence, using the PFB method makes it possible to determine the bottleneck factor that deters system performance, therefore assisting policymakers in deciding how policy resources should be allocated. Policies must continuously seek to handle the most poorly performing pillars first (Ács et al., 2018).

Further, the GEI index provides countries that want to develop entrepreneurship with the necessary policy tools. Even though the GEI policy framework is limited in prescribing interventions in the complex policy environment, it provides pointers that indicate existing bottlenecks. According to Szerb et al. (2016), this limitation comes from the fact that the GEI index only measures the national system of entrepreneurship partially. Dealing with these bottlenecks cannot be achieved with universal tools, but in-depth engagement with local policymakers and implementers is ideal (Szerb et al., 2016). 


\section{RESULTS AND DISCUSSION}

\section{Entrepreneurship and Small Business in the United Arab Emirates}

This section aims to provide a brief review of the entrepreneurial situation of UAE, summarizing the country's place in popular entrepreneurship, business, economy, and society-related international rankings.

Small and medium-sized enterprises (SMEs) are considered the backbone of the UAE's economy, accounting for $94 \%$ of all business in the country, which in turn employ $43 \%$ of the labor force. The UAE pays great attention to improving and supporting the performance of SMEs and facilitating their work environment. Additionally, SMEs are considered the core for economic growth and a vigorous supporter of the Emirates' GDP. In fact, their contribution to the Emirates' GDP is around 53\% (SMEs Report, 2019). However, UAE SMEs' competitiveness is lower than that of their counterparts, such as South Korea and Singapore, driven by low technology adoption needed to improve its services and competencies. SMEs also need to develop their overall corporate governance, particularly financial governance and transparency, to run in international markets and appeal to investors. There is still a lot to be done in the SMEs sector of UAE in enhancing the innovative environment for businesses to flourish and produce new goods and services and gain new market shares (SMEs Report, 2019; UAE Portal, 2020).

One of the most well-known rankings of entrepreneurship for countries is the Ease of Doing Business (EDB). UAE seems to perform very well in EDB. According to the World Bank (2019b), $50 \%$ of the adult population has an intention to start a new business within the coming three years, which positions the UAE first among the 190 participating countries. However, only $3.5 \%$ of the adult population has truly pursued a new business. Moreover, the UAE was ranked $1^{\text {st }}$ among the Arab countries and 11th internationally, due to facilities provided by the Emirate's government in terms of ease of paying taxes, issuing building licenses, property registration, getting electricity, and an improved online system for registering a business (UAE Portal, 2020). It is also among the most developing countries in EDB; this makes the UAE an entrepreneurial leader among the Arabian Gulf countries and the Middle East region in general. In fact, the UAE has a promising opportunity to progress among innovationdriven economies (World Economic Forum, 2018).

On average, the UAE's self-employment stands at 3.9\% compared to its neighbours, Saudi Arabia (Kingdom of Saudi Arabia, KSA) and Oman, record $4.8 \%$ and $3.4 \%$, respectively. It's much lower than the $30.58 \%$ Arab countries average, having shown slight improvement over the past five years. However, females are less active than males in self-employment at 3.6\% (World Bank, 2019a). The other popular ranking is the Global Competitiveness Index (GCI), where UAE ranked the UAE first in the Middle East and 25th worldwide, with its better ranking achieved in 2010 (23rd). The UAE witnessed substantial improvements in ICT adoption (2nd globally) and skills (39th) and was ranked first among the top 32 economies in a stable macroeconomic environment. Further, improvements in education and skills are required to boost the human capital required to drive innovation in the country (World Economic Forum, 2019).

This composite index is part of the Global Competitiveness Report issued by the World Economic Forum and reflects several areas such as ICT adoption, human capital, innovation capability, macroeconomic stability, and business dynamism (World Economic Forum, 2019).

Lastly, Regarding the Human Development Index (HDI), the UAE rates pretty high with $35^{\text {th }}$ place out of 189 participating countries encompassed in the report, and this sits UAE among very high human development class. However, UAE stills below the average of countries in the very high human development group. This index categories countries based on several indicators such as work, employment, education, usage of technology and communication, and trades and financial flows (UNDP, 2019).

\section{Entrepreneurship ecosystem in the United Arab Emirates}

According to GEI overall average score between 2012-2016, the UAE ranked 34th among the 95 listed countries with a GEI index of 44.6, with only one other Arab Gulf country Qatar (55.4), performing in the first-class group of countries, while Saudi Arabia in a latter class (40.2) (GEI, 2018). Also, the UAE's GEI score is far above the world average trend line. The 14 pillars in Table 2 offer a chance to realise how the 
Emirates' entrepreneurial ecosystem interacts. Generally, the ecosystem shows unequal performance. Start-up Skills (0.29) and Technology Absorption (0.18) are the sole pillars with a value below 0.30. All the pillars of the entrepreneurial aspiration sub-index show that the UAE is among the top-performing category of countries. It reflects that the country provides an adequate supporting environment for entrepreneurs to introduce new products or processes, connect international markets, and finance their business with venture capitals, which are crucial for pioneering start-ups (Ács et al.,2018).

Table 2. UAE's entrepreneurial profile at sub-indexes and pillars level between 2012-2016

\begin{tabular}{|l|l|c|}
\hline \multicolumn{1}{|c|}{ Sub-indexes } & \multicolumn{1}{|c|}{ PILLARS } & Score \\
\hline \multirow{5}{*}{ Entrepreneurial Attitudes (ATT) } & Opportunity Perception & 0.35 \\
\cline { 2 - 3 } & Start-up skills & 0.29 \\
\cline { 2 - 3 } & Risk Acceptance & 0.32 \\
\cline { 2 - 3 } & Networking & 1.0 \\
\cline { 2 - 3 } & Cultural Support & 0.84 \\
\cline { 2 - 3 } & ATT & $\mathbf{4 0 . 4}$ \\
\hline \multirow{5}{*}{ Entrepreneurial Abilities (ABT) } & Opportunity Startup & 0.60 \\
\cline { 2 - 3 } & Technology Absorption & 0.18 \\
\cline { 2 - 3 } & Human Capital & 0.87 \\
\cline { 2 - 3 } & Competition & 0.47 \\
\cline { 2 - 3 } & ABT & $\mathbf{3 5 . 1}$ \\
\hline \multirow{5}{*}{ Entrepreneurial Aspirations (ASB) } & Product Innovation & 1.0 \\
\cline { 2 - 3 } & Process Innovation & 0.63 \\
\cline { 2 - 3 } & High Growth & 0.90 \\
\cline { 2 - 3 } & Internationalization & 0.90 \\
\cline { 2 - 3 } & Risk Capital & 0.98 \\
\cline { 2 - 3 } & ASB & $\mathbf{5 8 . 5}$ \\
\hline
\end{tabular}

Source: own established based on GEI Dataset, 2012-2016.

Technology Absorption is a vital issue with a score less than 0.20 , it's evident to be the main bottleneck in the Emirates' entrepreneurial ecosystem, tailed by Startup Skills (0.29). Nevertheless, the UAE's overall performance is doing very well on the rest of pillars, and shortages in "Technology Absorption" and "Startup Skills" are probably to hinder the country's development in employing new opportunities, thus indicating that the country does not provide enough capacity for technology assimilation. Proposing that an investment in entrepreneurship practices and research competence might make additional developments in entrepreneurial achievement.

Table 3 displays additional analysis for the individual and institutional variables of GEI sub-indices. Generally, the Table presents unstable performance between individual and institutional variables in the Emirates' entrepreneurial ecosystem, where all institutional variables perform quite well, compared to individual variables that are witnessing major problems, mostly in the first two Sub-indexes. Overall institutional score (0.75) is mostly strong, with 7 out of 14 variables among the top $25 \%$ of the countries, and 4 variables among the third quartile of the countries. On the contrary, the least performing variables are Country Risk (0.61), Economic complexity (0.47), and education (0.41). However, Technology Transfer (1.0) ranks at best among the top $25 \%$ of countries, which indicates that the business setting in the UAE endorses the use of innovation for emerging new products (Ács et al., 2018).

Among individual variables in all sub-indices, the UAE has global leading results in "Human Capital", "Risk Capital", and "High Growth". For these pillars, the UAE's performance is almost optimal, which indicates its financial prosperity and the top resources of Human Capital. The UAE's situation as a vital trading center certainly delivers to superior scores of High growth and Internationalisation in this country. Overall, The UAE reveals a high rate of "Entrepreneurial Aspirations" and medium rates of "Entrepreneurial Abilities and Attitudes". As a result of this, UAE has a lower GEI score than it should be compared with other innovation-driven countries. 
Table 3. The Emirates' GEI Institutional and Individual Variables for 2020-1016

\begin{tabular}{|l|l|l|l|l|l|}
\hline \multicolumn{2}{|c|}{ PILLARS } & \multicolumn{2}{c|}{ INSTITUTIONAL VARIABLES } & \multicolumn{2}{c|}{ INDIVIDUAL VARIABLES } \\
\hline Opportunity Perception & 0.35 & Freedom & 0.62 & Opportunity Recognition & 0.39 \\
\hline Start-up skills & 0.29 & Education & 0.41 & Skill Perception & 0.67 \\
\hline Risk Acceptance & 0.32 & Country Risk & 0.61 & Risk Perception & 0.34 \\
\hline Networking & 1.0 & Connectivity & 0.98 & Know Entrepreneurs & 0.97 \\
\hline Cultural Support & 0.84 & Corruption & 0.74 & Career Status & 0.86 \\
\hline ATT & $\mathbf{4 0 . 4}$ & & - & - & - \\
\hline Opportunity Startup & 0.60 & Governance & 0.85 & Opportunity Motivation & 0.37 \\
\hline Technology Absorption & 0.18 & Technology Absorption & 0.88 & Technology Level & 0.00 \\
\hline Human Capital & 0.87 & Labor Market & 0.90 & Educational Level & 0.83 \\
\hline Competition & 0.47 & Competitiveness and Regulation & 0.82 & Competitors & 0.34 \\
\hline ABT & $\mathbf{3 5 . 1}$ & & - & & - \\
\hline Product Innovation & 1.0 & Technology Transfer & 1.00 & New Product & 0.81 \\
\hline Process Innovation & 0.63 & Science & 0.63 & New Technology & 0.91 \\
\hline High Growth & 0.90 & Finance and strategy & 0.95 & Gazelle & 0.75 \\
\hline Internationalization & 0.90 & Economic complexity & 0.47 & Export & 1.0 \\
\hline Risk Capital & 0.98 & Depth of Capital Market & 0.70 & Informal Investment & 1.0 \\
\hline ASB & $\mathbf{5 8 . 5}$ & -(Lubbadeh, 2019) & - & & - \\
\hline GEI & $\mathbf{4 4 . 6}$ & Institutional & $\mathbf{0 . 7 5}$ & Individual & - \\
\hline
\end{tabular}

Note: white: best $25 \%$; light grey: best $50 \%$; dark grey: worst 50\%; most shaded grey: worst $25 \%$.

Source: own elaboration source: based on GEI data 2012-2016 averages.

Even though the UAE technological absorption, which refers to acquisition, development, assimilation, and utilisation of technological knowledge and capability, is high at institutional level, the technology level that indicates technological sophistication at the firm level is not yet remarkable. It indicates the presence of very few new businesses or less percentage of start-ups in the technology sector. Getting a very low score in this variable is mainly because Emirates are not sufficiently educated and trained on the latest technologies and skills to start their own business (Hamdan, 2019; OECD, 2013). It could also be attributed to the lack of innovative and risk-taking people (Minhas, 2019; Hameed et al., 2016; OECD, 2013; Lubbadeh, 2019).

A high level of risk-aversion is not surprising; it may have deeper cultural reasons at a national level, if we look at the UAE's relatively high uncertainty avoidance score of 80 , which - along with the other cultural dimensions shown in Figure 1 (power distance, individualism, masculinity) - go hand in hand with the characteristics of the "Emirati entrepreneur profile" described by Minhas (2019), El-Sokari et al. (2013) and (OECD, 2013).

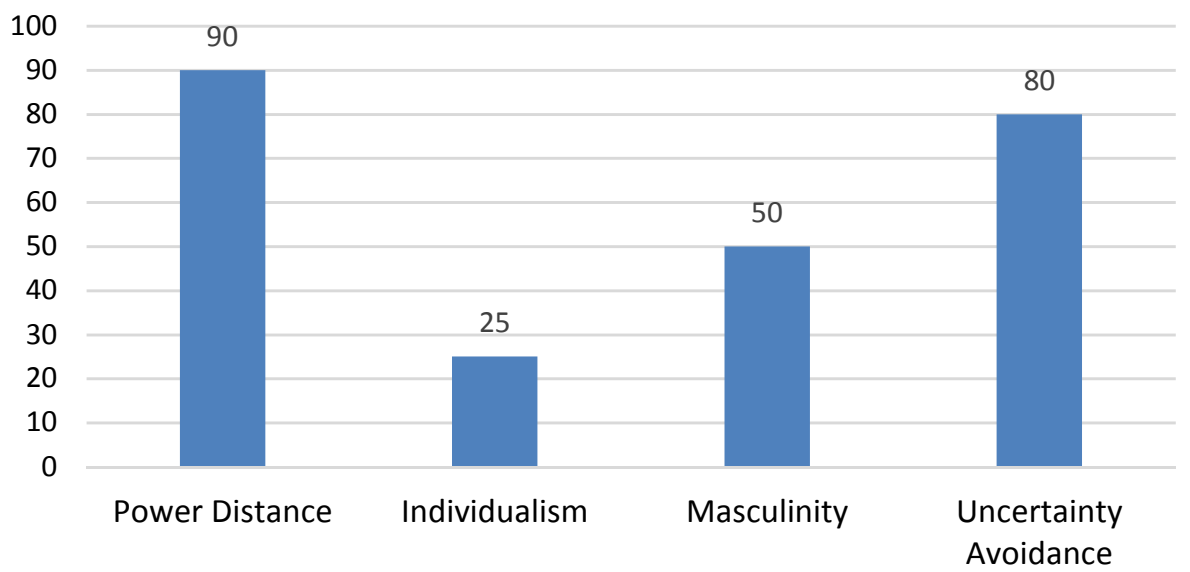

Figure 1. Hofstede's Cultural Dimensions in the UAE

Source: own elaboration based on Hofstede Insights (2020). 
Minhas (2019) associates the problem of this variable with the necessity for the proper environment that focuses on entrepreneurship education for individuals as the requirement to implement their business. There is also a large gap, presently, between entrepreneurial intentions and implementation in UAE, which is due to the continuing changes in rules, economic situation, rivalry, globalisation, innovation, financial barriers, and practices that make it more challenging for people to execute their intentions (Minhas, 2019; OECD, 2013).

The lack of the other variables can be attributed to several reasons; one of them is that the UAE population cannot recognise opportunities to begin a new business, and the institutional atmosphere does not promote these opportunities. The second one is that Emirati people are risk-averse; they are not enthusiastic about establishing a business due to the risky environment in the UAE because of instability in oil prices, reduction in the tourism stream, and restricted flexibility of the financial policy - this could be associated to the poor performance in risk perception (Global Edge, 2019).

It is essential to note that "Opportunity perceptions" which is one of the components of "opportunity start-up" is considered weak, which interprets that entrepreneurs are driven by necessity entrepreneurship, where the government does not make adequate actions or regulations to motivate entrepreneurs to start businesses. Therefore, it is vital to recognise what future entrepreneurs need out of their businesses, specifically, the aspiration to raise and scale up to the global level (Ács et al., 2018; Minhas, 2019).

\section{Comparing Emirates' Entrepreneurial performance to Saudi Arabia and Qatar}

Figure 2 compares the UAE to its neighbouring countries, Saudi Arabia, and Qatar. These countries also belong to the Arab States of the Persian Gulf, intending to enable and develop the economy between the Gulf members and across the globe. The major fields include the collaboration of policies and trade investment (UAE Portal, 2020). In the Gulf region, only the UAE and Qatar are categorised as innovation-driven countries, whereas Saudi Arabia is an efficiency-driven economy.

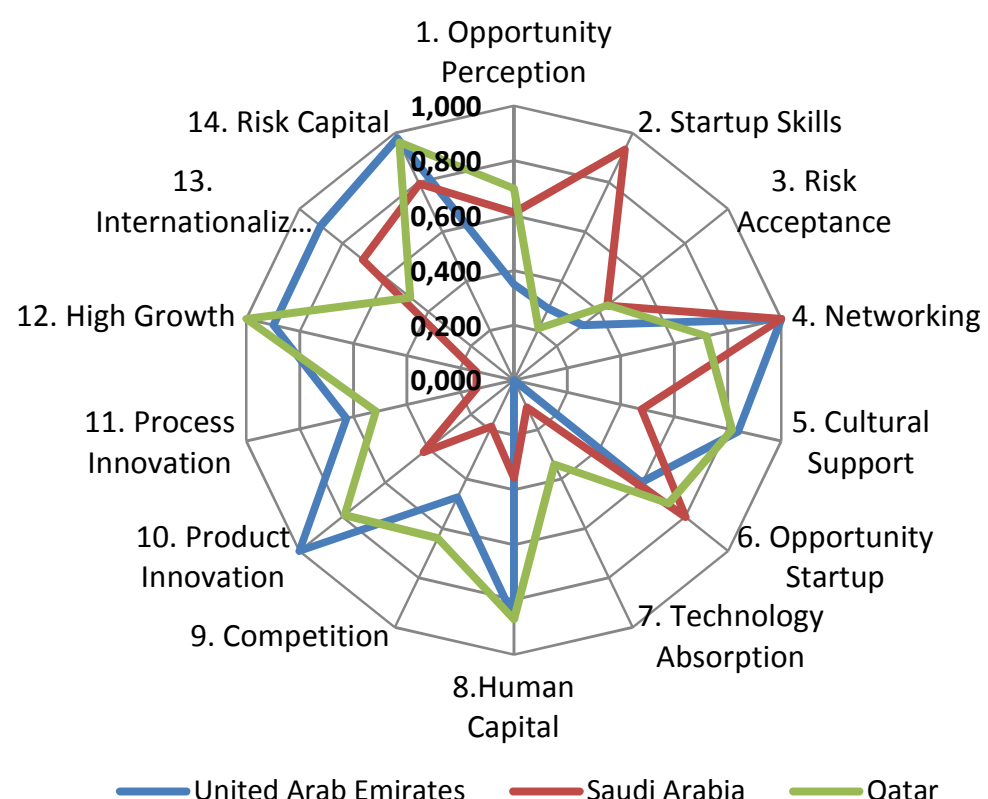

Figure 2. Pillar level compression of the UAE, Saudi Arabia, and Qatar for 2012-2016

Source: own elaboration based on GEI 2012-2016 dataset.

We can see in Figure 2 that the UAE and Qatar are the highest achievers in the Gulf region. They are also the top achievers internationally for several pillars, particularly Risk Capital, High Growth, and Human Capital. However, all three countries still face a significant bottleneck in Technology Absorption and Risk Acceptance, indicating that the technology sector in these countries does not have enough capacity for businesses to absorb new technologies rapidly, and the situation in these countries is relatively at high risk and individuals are not ready to take the risk for establishing businesses (Ács et al., 2018). 


\section{Enhancing Entrepreneurship in the UAE: A Simulation}

Analysis of this paper shows a specific bottleneck that requires intervention from the Emirates' government to make its entrepreneurial ecosystem conducive and enable entrepreneurs to achieve better performance in domestic and international markets.

Therefore, it is crucial to figure out the bottleneck pillars that hamper the government's endeavours in this area and make policy priorities. With the GEI penalty support for bottlenecks (PFB) methodology, the country can easily single out the bottleneck or the weakest pillars. Table 4 depicts the bottleneck variable of UAE and required efforts by the government to increase its GEI.

Table 4. reveals that policymakers need to dedicate their efforts to one pillar, "Technology Absorption", to boost the country's GEI score by $10 \%$. It is the major persistent bottleneck that demands $100 \%$ of the effort. As pointed out by the World Bank (2011), a more excellent technology absorption could "raise a country's economic productivity and strengthen growth competitiveness to gain ground in the global market". Furthermore, Yi et al. (2019) stated that technology absorption could be driven by universities, scientific research institutions, governments, and technology service agencies. Moreover, the World Bank (2011) proposed public policies and policy actions to improve nurturing technology absorption within a country.

Table 4. Simulation of maximising UAE GEI index average by 10 points for 2012-2016

\begin{tabular}{|c|c|c|c|c|}
\hline $\begin{array}{l}\text { "Sub-indexes } \\
\text { new score" }\end{array}$ & \multicolumn{2}{|l|}{ PILLARS } & $\begin{array}{l}\text { Required Increase } \\
\text { in pillar }\end{array}$ & $\begin{array}{c}\text { Percentage of the total } \\
\text { new effort }\end{array}$ \\
\hline \multirow{6}{*}{$\begin{array}{l}\text { Entrepreneurial } \\
\text { Attitudes }\end{array}$} & Opportunity Perception & & 0.0 & $0 \%$ \\
\hline & Start-up skills & & 0.0 & $0 \%$ \\
\hline & Risk Acceptance & & 0.0 & $0 \%$ \\
\hline & Networking & & 0.0 & $0 \%$ \\
\hline & Cultural Support & & 0.0 & $0 \%$ \\
\hline & ATT & 40.4 & & \\
\hline \multirow{5}{*}{$\begin{array}{l}\text { Entrepreneurial } \\
\text { Abilities }\end{array}$} & Opportunity start-up & & 0.0 & $0 \%$ \\
\hline & Technology Absorption & & 0.09 & $100 \%$ \\
\hline & Human Capital & & 0.0 & $0 \%$ \\
\hline & Competition & & 0.0 & $0 \%$ \\
\hline & $\begin{array}{r}\text { ABT } \\
\end{array}$ & 35.1 & & \\
\hline \multirow{7}{*}{$\begin{array}{l}\text { Entrepreneurial } \\
\text { Aspirations }\end{array}$} & Product Innovation & & 0.0 & $0 \%$ \\
\hline & Process Innovation & & 0.0 & $0 \%$ \\
\hline & High Growth & & 0.0 & $0 \%$ \\
\hline & Internationalisation & & 0.0 & $0 \%$ \\
\hline & Risk Capital & & 0.0 & $0 \%$ \\
\hline & $\begin{array}{r}\text { ASB } \\
\end{array}$ & 58.2 & & \\
\hline & GEI & 44.6 & & \\
\hline
\end{tabular}

Source: own calculations based on GEI index data 2012-2016 averages.

In general, public policy should first focus on getting the basics right - through fostering entrepreneurship, improving the investment climate, and strengthening competition. Since technology absorption and economic growth are strongly connected (Hamdan, 2019; Goldberg \& Kuriakose, 2011), the public policy of the UAE should provide a framework to increase technology absorption that focuses on investment climate and technology absorption capacity through training and education by targeting post-secondary schools and the labour force. Therefore, to harness all benefits of bolstering technology absorption, the UAE government needs to engage universities, scientific research institutions, enterprises, and technology intermediary service agencies in the process. 


\section{CONCLUSIONS}

This paper aimed to examine the entrepreneurship ecosystem of the UAE, Qatar, and Saudi Arabia by using the Global Entrepreneurship Index (GEI). The GEI proposes the multidimensional explanation of entrepreneurship by joining individual and institutional aspects to identify the ecosystem's weaknesses and strengths. The Penalty for Bottleneck (PFB) methodology helped us detect the country's worst-performing pillars (Technology Absorption) and recommend policy suggestions. Overall, the UAE ranked 34th, with $44.6 \mathrm{GEl}$ scores, among 95 countries in the index. Among other Arab Gulf countries, the UAE's GEI index was relatively higher, except Qatar, which scored 55.4. The GEI score of the United Arab Emirates and its sub-indices are all above the global average trend, and it lets the country count to the world's innovation-driven economies. As for the analysis of the 14 pillars: The UAE performs strongest in 7 of the $14 \mathrm{GEI}$ pillars, which places the country among the top countries in its category. However, its overall GEI performance is hampered by its weakest bottleneck pillar - "technology absorption" - under the entrepreneurial ability sub-index. Moreover, the level of GEI performance varies between institutional variables and individual variables. UAE performs much better in institutional variables than individual variables. Especially the individual variables within the Entrepreneurial Abilities sub-index, namely: opportunity motivation, technology level, and competitors, are the main problem areas that need the utmost attention from the government to strengthen the country's overall entrepreneurial abilities.

Moreover, the UAE's has a relatively higher GEI index in comparison with other Arab Gulf countries. Finally, we have used a particular feature of the GEI, the PFB bottleneck technique, to simulate the country position to boost its effectiveness by allocating more opportunities for advancing the entrepreneurship level in the UAE. The simulation indicates that the UAE should dedicate its resources on technology absorption to elevate its performance. UAE ranked $34^{\text {th }}$, with $44.6 \mathrm{GEI}$ scores, among the total of 95 countries in the index. Hence, we were able to deliver a comprehensive and multidimensional picture regarding the entrepreneurial performance in the UAE. Further to that, creating policy recommendations can assist in escalating its entrepreneurship performance by directing the most susceptible connection in the system.

Comparing the UAE's performance to the other two countries (Qatar and Saudi Arabia) in the region showed noteworthy results. UAE is leading in Internationalisation and Product Innovation. Risk capital, high growth, and human capital are the best performing pillars in both the UAE and Qatar, whereas process innovation and high growth pillars are the worst in the Saudi Arabia, and start-up skill is the worst performing pillar in Qatar. However, all three countries are still facing a significant bottleneck in technology absorption and risk acceptance. Overall, the UAE is not performing well compared to other average performers in its category of innovation-driven economies. In conclusion, there is a necessity for policy involvement to handle the present bottlenecks, mainly to improve technology absorption. Lastly, the UAE government has to make more effort in technology absorption, as the country calls for 0.09 extra resources ( $100 \%$ new effort allocation) to enhance the GEI score by $10 \%$, which implies that the UAE needs to apply a variety of improvements to boost the entrepreneurship ecosystem.

As a constraint, the GEI data used in the study only cover the 2012-2016 period. Hence further analyses are vital to cover a longer or more up-to-date timeframe than the period used in the trial, mainly if there are changes in government policies after that period. We contribute to recognizing the vulnerability in the entrepreneurial profile of UAE in the sub-indexes, pillars, and component variables. In particular, the study reveals observational evidence of a lack of entrepreneurship in the population as the basis for moderate success. Besides, we employed the PFB approach to underline the country's bottlenecks and offer estimated recommendations about how UAE could improve its bottleneck.

\section{REFERENCES}

Ács, Z., Autio, E., \& Szerb, L. (2014). National Systems of Entrepreneurship: Measurement issues and policy implications. Research Policy, 43(3), 476-494. https://doi.org/10.1016/j.respol.2013.08.016

Ács, Z., Szerb, L., \& Lloyd (2018). The Global Entrepreneurship Index 2018. The Global Entrepreneurship and Development Institute, Washington, D.C., USA Cham: Springer Briefs in Economics. doi:10.1007/978-3-030-03279-1 
Al Saiqal, N.Y., Ryan, J.C., \& Parcero, O.J. (2018). Entrepreneurial Intention and UAE Youth: Unique Influencers of Entrepreneurial Intentions in an Emerging Country Context. Journal of East-West Business, 25(2), 144-165. https://doi.org/10.1080/10669868.2018.1536012

Cummings, J.C. (2018) 'The Price Is Rights: Getting the United Arab Emirates up to International Speed in the Labor Law Department'. Brooklyn Journal of International Law, (Issue 1), p. 410. Retrieved from https://brooklynworks.brooklaw.edu/bjil/vol44/iss1/10 on December 12, 2020

El-Sokari, H., Horne, V., Huang, V.Z., \& Awad, A. (2013). Entrepreneurship: An Emirati Perspective. Institute of Social \& Economic Research (ISER)- Zayed University. ISBN: 978-9948-20-041-3

GEM Global Entrepreneurship Monitor (GEM). (2018). Entrepreneurship in the United Arab Emirates. Retrieved from https://www.gemconsortium.org/report/gem-2018-2019-global-report on December 17, 2020.

Global Edge. (2019). United Arab Emirates: Risk Assessment. Retrieved from https://globaledge.msu.edu/countries/united-arab-emirates/risk on December 19, 2020.

Goldberg, I., \& Kuriakose, S. (2011). Fostering technology absorption in Southern African enterprises. Washington, DC: World Bank. https://doi.org/10.1596/978-0-8213-8818-1

Głodowska, A., Pera, B., \& Wach, K. (2016). The International Environment and Its Influence on the Entrepreneurial Internationalization of Firms: The Case of Polish Businesses. Problemy Zarzqdzania, 14(3), 107-130. https://doi.org/10.7172/1644-9584.62.7

Hamdan, A. M. M. (2019). Entrepreneurship and Economic Growth: An Emirati Perspective. The Journal of Developing Areas, 53(1), 65-78. https://doi.org/10.1353/jda.2019.0004

Hameed, I., Khan, M., Shahab, A., Hameed, I., \& Qadeer, F. (2016). Science, Technology and Innovation through Entrepreneurship Education in the United Arab Emirates (UAE). Sustainability, 8(12), 1280. https://doi.org/10.3390/su8121280

Hofstede Insights (2020). The United Arab Emirates. Retrieved from https://www.hofstede-insights.com/country/the-united-arab-emirates/ on December 15, 2020.

Khan, M.R. (2016). Entrepreneurship ecosystem evolution strategy of Saudi Arabia. International Entrepreneurship Review, 2(2), 67-92.

Khalilov, L., \& Yi, C.-D. (2021). Institutions and entrepreneurship: Empirical evidence for OECD countries. Entrepreneurial Business and Economics Review, 9(2), 119-134. https://doi.org/10.15678/eber.2021.090208

Lane, P. M. (2016). Creating the environment for innovation and entrepreneurship. International Entrepreneurship Review, 2(2), 53-66.

Lubbadeh, T. (2019). Entrepreneurship development in Japan: An empirical analysis. International Entrepreneurship Review, 5(3), 19-33. https://doi.org/10.15678/ier.2019.0503.02

Minhas, W.A. (2019). Advancing Entrepreneurship in the United Arab Emirates: start-up challenges and opportunities. Palgrave Macmillan. Retrieved on Dec. 17, 2020, from https://books.google.hu/books?id=zE5aDwAAQBAJ

OECD (2013). The Entrepreneurial Ecosystem of Abu Dhabi: Boosting the entrepreneurial ecosystem: UAE. Retrieved from https://www.oecd.org/countries/unitedarabemirates/AbuDhabi-Ecosystem-Final-Web.pdf on May, 24, 2020.

Rahatullah, M.K. (2014). Role of Trust and Commitment in Building Successful Franchise Business Relationships. International Journal of Knowledge, Innovation and Entrepreneurship, 2(1), 90-107.

SMEs Report. (2019). The state of small and medium enterprises (SMEs). In Dubai SME (pp. 16-20). Retrieved from https://sme.ae/SME_File/Files/SME\%20STATE\%202019\%20AR.pdf on July 24, 2020.

Szerb, L., \& Trumbull, W.N. (2018). Entrepreneurship development in Russia: is Russia a normal country? An empirical analysis. Journal of Small Business and Enterprise Development, 25(6), 902-929. https://doi.org/10.1108/jsbed-01-2018-0033

Szerb, L., Komlosi, E., \& Páger, B. (2016). Measuring entrepreneurship and optimising entrepreneurship policy efforts in the European Union. CESifo DICE Report, 14, 8-23. Retrieved from https://www.econstor.eu/bitstream/10419/167269/1/ifodice-report-v14-y2016-i3-p08-23.pdf on December 17, 2020,

UAE (2020). The United Arab Emirates' Government Portal. Retrieved from https://u.ae on December 17, 2020,

UAE Portal. (2019). Annual Economic Report. Retrieved from https://u.ae/en/about-the-uae/economy on December 17, 2020. 
Ubrežiová, I., Wach, K., \& Horváthová, J. (2008). Entrepreneurship in small and medium-sized enterprises: Comparative study between Slovakia and Poland for the years 2001-2007. Agricultural Economics, 54(8), 358-366

UNDP (2019). Human Development Report. Retrieved from http://hdr.undp.org/sites/all/themes/hdr_theme/ country-notes/ARE.pdf on May 15, 2020.

Wach, K. (2015). Small and Medium-sized Enterprises in the Modern Economy (chapter 7). In M.R. Contreras Loera \& A. Marjański (Eds.), The Challanges of Management in Turbulent Times. Global Issues from Local Perspective. Occidente (México): Universidad de Occidente, pp. 77-101

Wach, K., \& Głodowska, A (2021). How do demographics and basic traits of an entrepreneur impact the internationalisation of firms?. Oeconomia Copernicana, 12(2).

World Bank (2019a). United Arab Emirates. Retrieved from https://data.worldbank.org/indicator/SL.EMP.SELF.ZS?locations=AE on May 22, 2020.

World Bank (2019b). Doing Business 2019. Retrieved from https://www.doingbusiness.org/content/dam/doingBusiness/media/Annual-Reports/English/DB2019-report_web-version.pdf on May 16, 2020.

World Bank. (2011). Fostering Technology Absorption in Southern African Enterprises. World Bank. Washington, DC. USA.

World Economic Forum. (2019). The Global Competitiveness Report. Retrieved from http://www3.weforum.org/docs/WEF_TheGlobalCompetitivenessReport2019.pdf on December 17, 2020.

Yi, M., Fang, X., \& Zhang, Y. (2019). The Differentiated Influence of Technology Absorption on Regional Economic Growth in China. Sustainability, 11(2), 450. https://doi.org/10.3390/su11020450

\section{Author}

\section{Ayman Balawi}

PhD Candidate in Business Administration at the University of Pécs (Hungary); Master's in business administration (2017, Birzeit University, Palestine); Bachelor of Electronics Engineering with minor in physics in (2011, Palestine Polytechnic University, Palestine). His research interests include the relationship between transformational and transactional leadership and their impact on Innovative behaviours, entrepreneurship, social media marketing.

Correspondence to: Mr. Ayman Balawi, Faculty of Business and Economics, Pécs, Rákóczi út 80, 7622, Hungary, e-mail: aymanalb2004@gmail.com

ORCID (1) http://orcid.org/0000-0002-4500-5337

\section{Acknowledgements and Financial Disclosure}

The author would like to express his appreciation to Prof. László Szerb, who provided the GEI dataset, and for his priceless comments and directions in this paper.

\section{Conflict of Interest}

The author declare that the research was conducted in the absence of any commercial or financial relationships that could be construed as a potential conflict of interest.

\section{Copyright and License}

This article is published under the terms of the Creative Commons Attribution - NoDerivs (CC BY-ND 4.0) License http://creativecommons.org/licenses/by-nd/4.0/ 